\section{Competition Between Vegetative and Reproductive Growth in Cranberry}

Justine E. Vanden Heuvel ${ }^{1,2}$ and Carolyn J. DeMoranville

University of Massachusetts Amherst, Cranberry Experiment Station, 1 State

Bog Road, P.O. Box 569, East Wareham, MA 02538

Additional index words. Vaccinium macrocarpon, yield potential, source-sink relationships

Abstract. Competition between reproductive and vegetative growth has not been studied in cranberry. The objective of this research was to assess the growth patterns of leaves and fruit in three cranberry cultivars to determine whether vegetative and reproductive growth compete for resources. 'Stevens', 'Howes', and 'Early Black' uprights and fruit were collected on a weekly basis in 2002 and on a biweekly basis in 2003 and 2004 from a research bog in Massachusetts. Although growth was affected by cultivar and year, data indicated a general shifting of resource allocation from leaf area and dry weight accumulation to fruit growth at $\approx 1500$ growing degree days (GDD, base $4.4{ }^{\circ} \mathrm{C}$ ), when the initial surge of fruit growth began. Leaf area and dry weight accumulation resumed at $\approx 2300$ GDD, resulting in a competition for resources with the developing fruit until after 3000 GDD. A lag phase in fruit diameter and dry weight accumulation was noted in some years and some cultivars and may be partially the result of the resumption of leaf growth at 2300 GDD. Fruit and shoot growth appear to compete for resources in late July through early August in Massachusetts, when carbohydrate concentration of uprights and roots is extremely low. based on two wild selections from native cranberry stands, 'Early Black' and 'Howes'. 'Early Black' is the predominant cranberry cultivar in Massachusetts (DeMoranville, 2004). The fruit of 'Early Black' are dark in color and ripen early, usually during the first 2 weeks of September. The vines are finetextured, have few runners, and many uprights. The leaves are small and light green. 'Howes', a late-maturing cultivar, originated as a native selection in Massachusetts. Vines are coarse with many uprights and comparatively few runners; leaves are large and dark green. 'Howes' has been described as less productive than 'Early Black' (Dana, 1983), but this has not been our observation in Massachusetts cultivation. In 1950 , the USDA cranberry breeding program released 'Stevens', which was selected based on its large fruit size and productivity (Roper, 2001). It now accounts for a large proportion of the cranberry industry in Wisconsin and the Pacific Northwest and is being planted with greater frequency in Massachusetts (Roper, 1999).

Little attempt has been made to document the growth of both fruit and vines in a modern
The American cranberry (Vaccinium macrocarpon Ait.) is a woody, nondecidious, low-growing perennial. Horizontal stolons (called "runners") lie on the soil surface and allow the vine to spread. Fruit are borne on short vertical shoots (called "uprights") that can originate from the node of a runner or from the terminal or axillary buds of other uprights. Uprights can produce either vegetative or mixed buds. Individual uprights generally bear fruit biennially, but because cranberry bogs are populated by a large number of uprights, overall yield does not usually alternate (Roper et al., 1993). The most important components in cranberry yield, in decreasing order, are fruit set, berry size, and the number of flowers per centimeter of upright (Baumann and Eaton, 1986). Failure of upper fruit on an upright to develop is likely the result of depletion of carbohydrate resources during the initial stages of fruit set (Birrenkott and Stang, 1990).

The Massachusetts cranberry industry began in the 1800 s and has historically been

Received for publication 28 July 2008. Accepted for publication 19 Nov. 2008.

This research was supported by USDA/CSREES, the Massachusetts Agr. Expt. Sta. Project MAS00875, the Cape Cod Cranberry Growers' Association, Ocean Spray Cranberries, Inc., and the UMassAmherst Cranberry Experiment Station.

We gratefully acknowledge the technical assistance of Ellen Unruh, Amber Awad, and Michelle Salvas and thank Rebecca Harbut and Hilary Sandler for their assistance with this manuscript. ${ }^{1}$ Current address: Department of Horticultural Sciences and Department of Horticulture, Cornell University, NYSAES, 630 West North Street, Geneva, NY 02538.

${ }^{2}$ To whom reprint requests should be addressed; e-mail jev32@cornell.edu.
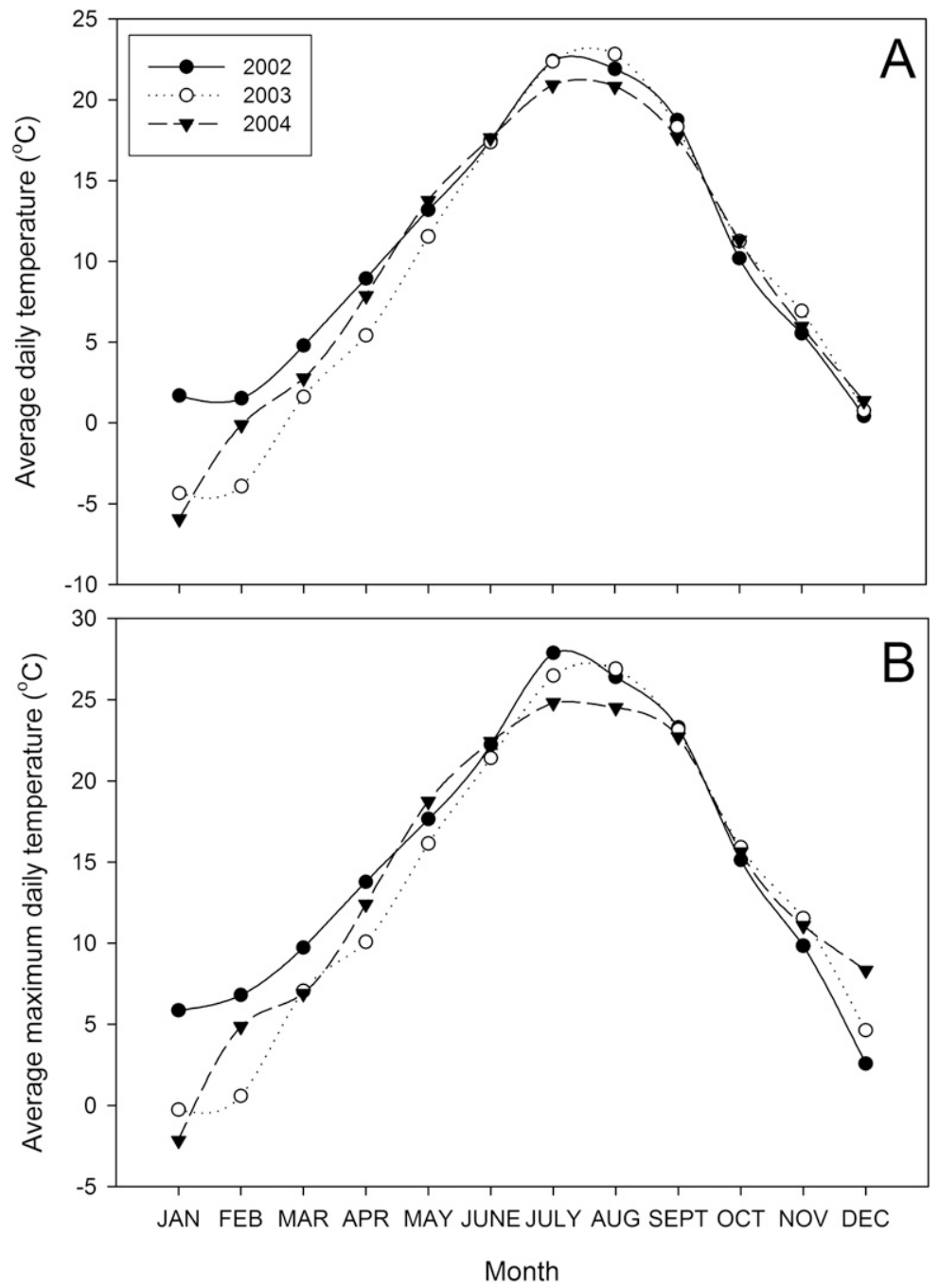

Fig. 1. (A) Average daily temperature; and (B) average maximum daily temperature at State Bog in Wareham, MA, 2002 to 2004. 
commercial cranberry production setting. Chandler (1952) originally described the growth of 'McFarlin', 'Early Black', and 'Howes' fruit to be an asymptotic curve, in which little growth occurs after early September. At that time, fertilizer use in cranberry production was limited, so growth patterns in current production could be expected to differ. More recently, DeMoranville (1992) studied both vegetative and reproductive growth of 'Early Black' in Massachusetts. Growth patterns of 'Stevens', 'Crowley', and 'Pilgrim' fruit in several cranberry regions have also been reported (DeMoranville et al., 1996). Although several studies regarding the effect of fertilizer nitrogen on cranberry vegetative and reproductive biomass production exist (Davenport, 1996; Davenport and Vorsa, 1999; DeMoranville, 1992; Vanden Heuvel and Davenport, 2006), a comprehensive study of both vegetative and reproductive growth patterns for multiple cranberry cultivars is lacking in the literature. This information is important, because a thorough understanding of resource allocation throughout the season is required as the framework within which the effects of cultural practices on carbon status of the vine can be assessed. The objective of this study was to produce a set of growth curves of cranberry leaves and fruit as the basis for determining key times of competition among organs through the growing season.

\section{Materials and Methods}

Sample collection. 'Stevens', 'Howes', and 'Early Black' uprights were collected on a weekly basis in 2002 and on a biweekly basis in 2003 and 2004 from State Bog at the University of Massachusetts Amherst Cranberry Experiment Station located in E. Wareham, MA (lat. $41^{\circ} 45^{\prime} \mathrm{N}$, long. $70^{\circ} 40^{\prime} \mathrm{W}$ ). Three sections of bog (each planted with one cultivar) were divided into four $25-\mathrm{m}^{2}$ plots, from which two subsamples were randomly collected at each sampling date. The cultivars were growing within the same management unit and were treated similarly throughout the experiment. Sample collection involved collecting all uprights present within a randomly placed $15.2-\mathrm{cm}$ diameter ring. Uprights were cut at soil level, placed into plastic resealable bags, and stored at $3{ }^{\circ} \mathrm{C}$ until analyzed.

Sample analysis. Uprights from each sample were counted, and 10 uprights were randomly selected for further analysis. Diameter of each fruit that had developed beyond style fall was measured twice using digital calipers. Leaves were removed and leaf area quantified using a leaf area meter (LI 3100; LI-COR, Lincoln, NE). Leaves and fruit were put into separate bags and dried at $80{ }^{\circ} \mathrm{C}$ for a minimum of $5 \mathrm{~d}$, after which dry weights were taken.

Data analysis. Normality of data was tested and outliers were removed so that all assumptions were met. Data were expressed based on growing degree days so that the results can be applied to growing regions outside of Massachusetts. Temperature data were recorded by a weather station on the bog (Fig. 1). Growing degree days (GDD) (Fig. 2) were calculated using a base of $4.4^{\circ} \mathrm{C}$ (based on DeMoranville, 1992). GDD were accumulated from 1 Jan. each year based on observations by Massachusetts growers and researchers that bogs not subjected to flooding in the winter (and therefore more exposed to temperature fluctuations) are advanced phenologically when growth begins (late May) when warm weather has occurred January through March (C. DeMoranville, pers. comm.). Therefore, beginning on 1 Jan. of each year, average daily temperature (ADT) was calculated so that:

$\mathrm{ADT}=$

minimum temperature + maximum temperature 2

Accumulated GDD were then calculated using the following parameters:

If $\mathrm{ADT}>4.4{ }^{\circ} \mathrm{C}$, then $\mathrm{GDD}=\mathrm{ADT}-4.4$

${ }^{\circ} \mathrm{C}$; and

If $\mathrm{ADT}<4.4{ }^{\circ} \mathrm{C}$, then GDD $=0$.

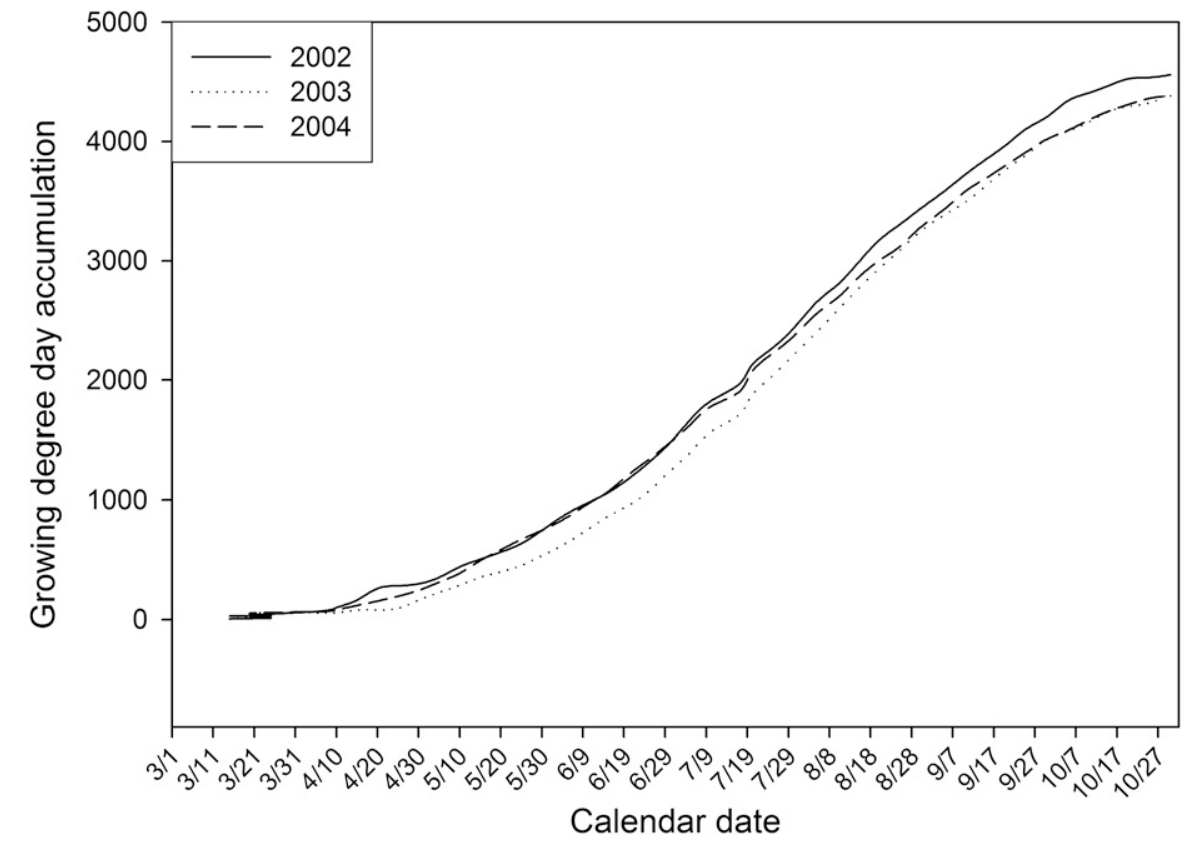

Fig. 2. The relationship between calendar date and growing degree day accumulation (base $4.4^{\circ} \mathrm{C}$ ) in 2002 , 2003, and 2004 at State Bog in Wareham, MA.

Table 1. Total water availability (rainfall + irrigation) in June, July, and August of each year at State Bog, E. Wareham, MA.

\begin{tabular}{lcccc}
\hline Study & Year & $\begin{array}{c}\text { June rainfall }+ \\
\text { irrigation }^{\mathrm{z}}(\mathrm{cm})\end{array}$ & $\begin{array}{c}\text { July rainfall }+ \\
\text { irrigation }(\mathrm{cm})\end{array}$ & $\begin{array}{c}\text { August rainfall + } \\
\text { irrigation }(\mathrm{cm})\end{array}$ \\
\hline Present study & 2002 & 14.2 & 11.2 & $8.1^{\mathrm{y}}$ \\
Present study & 2003 & 14.0 & 10.7 & 9.9 \\
Present study & 2004 & 10.4 & 6.9 & 19.0 \\
DeMoranville (1992) & 1986 & 8.4 & 17.0 & 13.0 \\
DeMoranville (1992) & 1987 & 8.6 & 5.8 & 10.4 \\
DeMoranville (1992) & 1988 & 9.7 & 21.6 & 7.4 \\
DeMoranville (1992) & 1989 & 12.2 & 15.7 & 17.0 \\
\hline
\end{tabular}

${ }^{\mathrm{z}}$ Assumes $0.38 \mathrm{~cm}$ per hour for irrigation system.

${ }^{\mathrm{y}}$ Incomplete record, likely missing some irrigation events over month of Aug. 2002.
Least square means and SES of the means were calculated using Proc GLM in SAS v. 8 (SAS Institute, Cary, NC). Because the cultivars were not planted in a replicated , we did not test for differences among cultivars. Differences among years (within a the means did not overlap.

\section{Results and Discussion}

Vegetative and reproductive growth of 'Early Black', 'Stevens', and 'Howes' cran(hifuticantly in climatic dry year with higher average maximum daily temperatures in July compared with 2003 and 2004 and higher average daily temperatures in July compared with 2004 (Fig. 2). Year 2003 was a cooler growing season, particularly in the spring (Fig. 2). Accumulated GDD on 30 Oct. in 2002, 2003, and 2004 were 4558, 4382, and 4404, respectively (Fig. $2)$. Although precipitation patterns varied among years (data not shown), sprinkler irrigation was used on the bog to supply vines with water. Total water availability berries were studied over three growing patterns (Figs. 1 and 2). Year 2002 was a hot (rainfall + irrigation) was lower in June and 
July but higher in August in 2004 compared with 2002 and 2003 (Table 1).

Dry weight accumulation of uprights on a ground area basis (15.2-cm diameter ring) followed a similar pattern among years (Fig. 3), particularly in 'Howes' and 'Stevens'. 'Early Black' produced about the same weight of leaves on a ground area basis in 2002 as in 2003; dry weight of leaves was lower in 2004 (Fig. 3A). Upright number per ring (i.e., upright density) was similar in 2002 and 2003 in 'Early Black' but lower in 2004 (data not shown). Leaves in 'Howes' (Fig. 3B) and 'Stevens' (Fig. 3C) plots accumulated less dry weight in 2002 compared with 2003 and 2004 and had fewer uprights per ring in 2002 compared with 2003 (data not shown). It appears that differences in leaf dry weight on a per area basis are accounted for by differences in upright density.

In all cultivars, dry weight of leaves generally decreased early in the season, presumably as a result of loss of 1-year-old leaves from the upright. Leaf dry weight increased from $\approx 800$ GDD to $\approx 1700 \mathrm{GDD}$ (1 June to 7 July in 2002; 13 June to 15 July in 2003; and 3 June to 8 July in 2004) and then decreased slightly followed by a small peak of increase at $\approx 3000$ GDD (16 Aug. in 2002; 22 Aug. in 2003; 20 Aug. in 2004) in all cultivars and years with the exception of 'Early Black' in 2004. A decrease in dry weight of woody stems and old leaves of 'Early Black' was noted by DeMoranville (1992) early in the growing season and coincided in timing with the decrease in dry weight reported here followed by a peak in dry weight beginning earlier in the spring than reported here. However, because new and old growth were combined in this experiment, the decline in weight of old tissues in the early spring may mask early gains in weight of new growth, giving the appearance of a later start to leaf mass accumulation (400 GDD in the previous work versus 800 GDD here). The peak in leaf dry weight at $\approx 1700$ GDD in this study coincides with a peak in growth of new shoots reported by DeMoranville (1992). Although leaf dry weight was lower in 'Howes' and 'Stevens' in 2002 compared with the other years, the pattern of dry weight accumulation was similar between cultivars and years.

Interestingly, although the leaf dry weight in 'Howes' (Fig. 3B) and 'Stevens' (Fig. 3C) was less in 2002 compared with 2003, leaf dry weight in 'Early Black' was similar in the 2 years (Fig. 3A). The decreased growth generally noted in 2002 (Figs. 3 and 4) may be the result of heat, because 2002 was a hot year compared with 2003 (Fig. 2), particularly in July (Fig. 2B), although water availability was comparable between the two seasons (Table 1).

Total leaf area per upright (current year + 1 -year-old leaves) was generally much lower for most of the 2002 growing season (Fig. 4) and did not change much over the season compared with other years, likely the result of limitation of carbon assimilation by the high temperatures of that season. Decreases
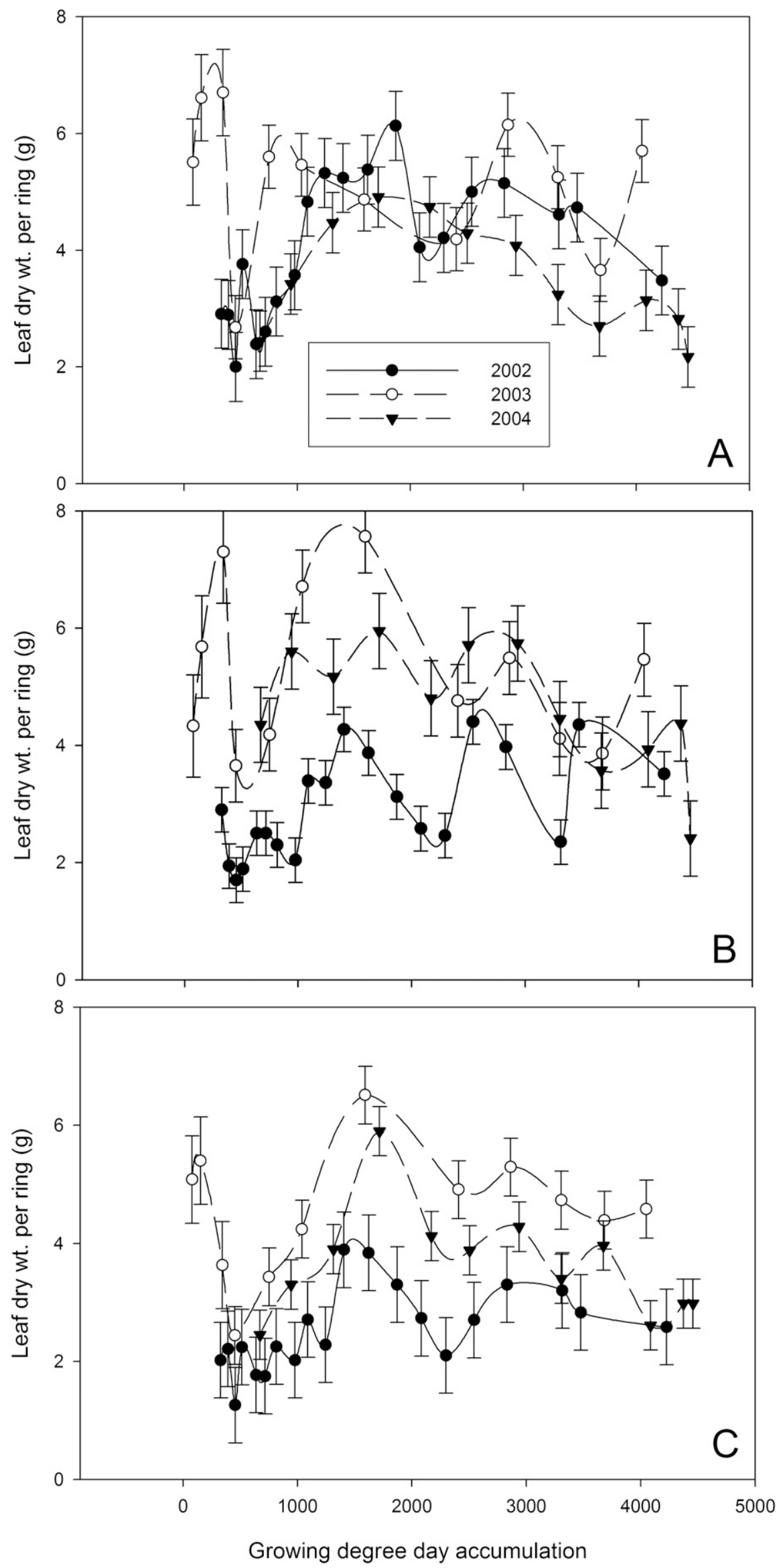

Fig. 3. Total leaf dry weight per ring (15.2 cm diameter) in 2002, 2003, and 2004 for (A) 'Early Black', (B) 'Howes', and (C) 'Stevens' cranberry in East Wareham, MA. 

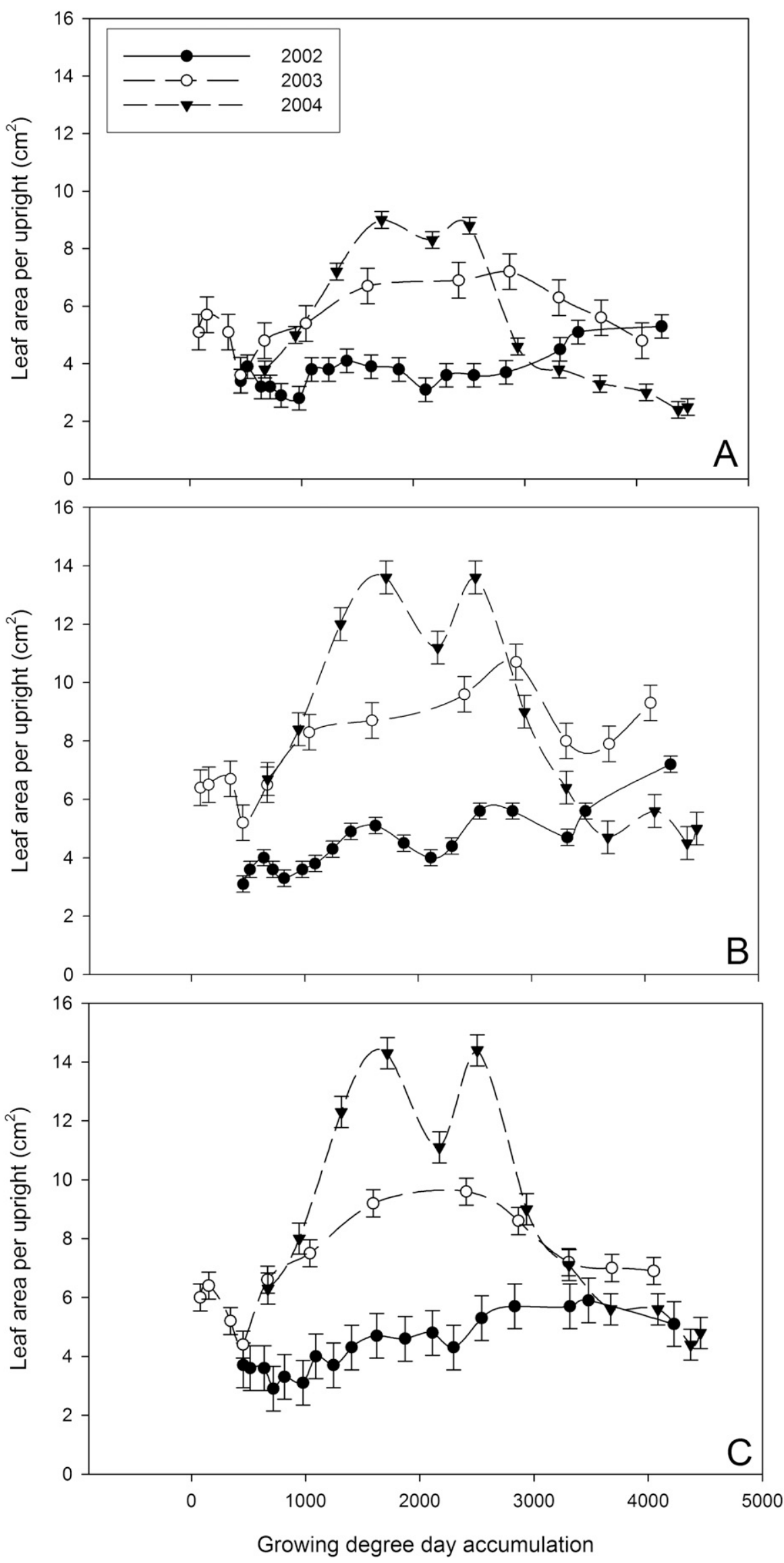

Fig. 4. Leaf area per upright in 2002, 2003, and 2004 of (A) 'Early Black', (B) 'Howes', and (C) 'Stevens' cranberry in East Wareham, MA. in leaf area per upright coincided with decreases in leaf dry weight in 2002 (Fig. 3) and may be the result of the loss of older leaves throughout the season (Vanden Heuvel and Davenport, 2006). Leaf area increased slightly through the season in 2003 with a peak occurring at $\approx 2800$ GDD (10 Aug.) in all cultivars (Fig. 4). Leaf area per upright was generally higher in 2004 than in the previous years of the study, particularly in the early portion of the growing season. This increase in leaf area compared with other years is likely not linked to water availability, because rainfall and irrigation were limited in July 2004 (Table 1). A rapid increase in leaf area occurred between 1000 and 1700 GDD (12 June to 8 July). In 'Early Black' and 'Stevens', an increase in leaf dry weight occurred concurrently (Figs. 3A and 3C). Another peak in leaf area of 'Howes' and 'Stevens' uprights was noted at $\approx 2600$ GDD (7 Aug.) (Fig. 4B-C), and then leaf area per upright decreased rapidly. As a nondecidious perennial, cranberry plants produce new leaves beginning in early June, retain those leaves through the winter, and begin to drop those leaves in the early spring of the second year, before the onset of the next year's leaf production. The plants continue to lose the older leaves through the summer, likely accounting for the observed loss in leaf area late in summer. At that time, new leaf production for the season is complete while the previous year's leaves continue to drop. To our knowledge, development of leaf area per upright throughout the season has not been previously documented in the scientific literature for any cranberry cultivar except 'Stevens' (Vanden Heuvel and Davenport, 2006).

Berry size has been determined to be the second most important component in cranberry yield (Baumann and Eaton, 1986). The pattern of growth with respect to fruit diameter and fruit dry weight accumulation was affected by year as indicated by separation of SEs. In 2002, diameter of fruit from all cultivars demonstrated a double-sigmoid growth pattern (Fig. 5), with the lag phase occurring from $\approx 2600$ GDD to 3300 GDD (4 Aug. to 25 Aug.). This lag in growth may have been the result of lack of water availability to the vine. August 2002 was a dry month (Table 1); unfortunately, irrigation records for State Bog are incomplete for that month, so supplemental water may or may not have been provided during this phase. A lag phase was not visible in 'Early Black' in 2003 (Fig. 5A); however, in 2004, a slight lag phase occurred again from 2600 to 3300 GDD (7 Aug. to 31 Aug). 'Howes' did not demonstrate a lag phase in 2004, but did have one in 2003 over about the same period (Fig. 5B). 'Stevens' had an exponential growth curve with respect to fruit diameter in 2003 and 2004 (Fig. 5C).

Growth curves for fruit dry weight (Fig. 5D-F) looked similar to those for fruit diameter, indicating that fruit dry matter accumulation and fruit expansion are closely linked. 'Early Black' and 'Stevens' showed a slight lag phase in growth in 2002, although a lag phase was not particularly evident in 

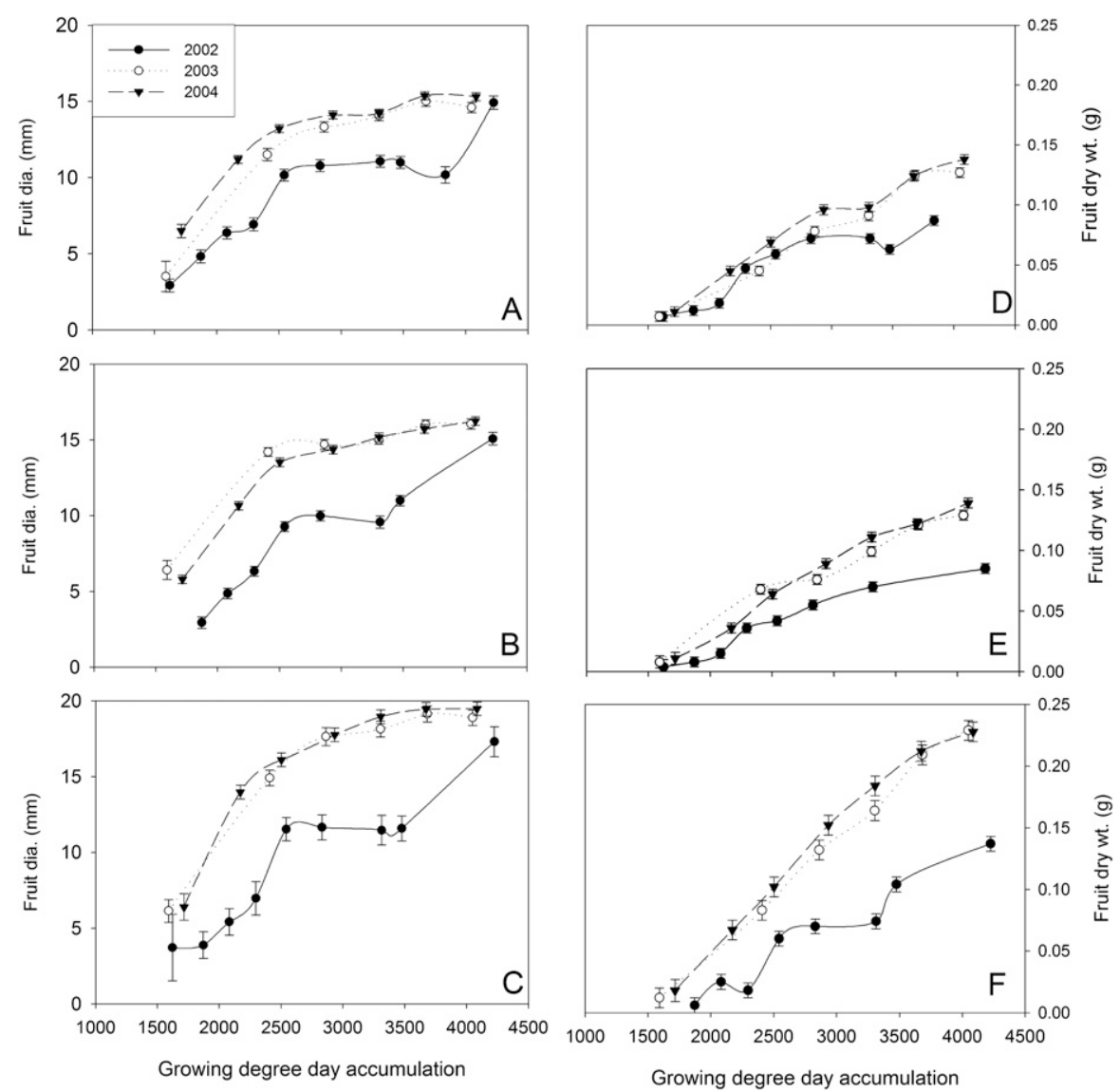

Fig. 5. Average fruit diameter in 2002, 2003, and 2004 of (A) 'Early Black', (B) 'Howes', and (C) 'Stevens' cranberry; average fruit dry weight of (D) 'Early Black', (E) 'Howes', and (F) 'Stevens' cranberry in East Wareham, MA.

'Howes' (Fig. 5B). Dry weight accumulation was essentially linear in 'Early Black' in 2003 (Fig. 5A) but demonstrated a slight lag phase (2800 to 3300 GDD; 14 Aug. 14 to 31 Aug.) in 2004. 'Howes' demonstrated a small lag phase in 2003 (2400 to 2900 GDD; 5 Aug. to 20 Aug.); however, dry weight accumulation was linear in 2004 (Fig. 5B). 'Stevens' demonstrated linear dry weight accumulation in 2003 and 2004 (Fig. 5C) with no peak in fruit growth evident by harvest. The variability in the shape of these growth curves indicates that growth and expansion of cranberry fruit may be affected by a number of factors such as environmental conditions and production practices.

The description of cranberry fruit growth curves in the literature is contradictory. A linear relationship between fresh weight and date was demonstrated in 'Stevens', 'Pilgrim', and 'Crowley' over five production areas in 1992 and 1993 (DeMoranville et al., 1996), but the earliest stages of fruit growth were not included in that study. Hawker and Stang (1985) also showed a linear relationship between fresh or dry weight accumulation of 'Searles' and 'Ben Lear' and GDD; Chandler (1952) originally described the growth curve for cranberry fruit fresh weight as a single initial growth surge that is sustained and said that little change in berry weight occurred after early September for 'Howes' and 'Early Black' in Massachusetts.
In contrast, DeMoranville (1992) demonstrated a linear increase in the dry weight of 'Early Black' in 1987 and 1989 (with significant increases in dry weight between early September and harvest) and an asymptotic relationship between date (expressed as either day number or GDD) and fruit weight in 1986 and 1988. However, although the linear regression is significant, a short lag phase is evident in the fresh weight and dry weight data from 1987 and 1988 in 'Early Black' (DeMoranville, 1992). Interestingly, those 2 years (1987 and 1988) were somewhat dry with significant water deficits occurring on State Bog in July 1987 and August 1988 (Table 1). A lag phase in growth has not been clearly demonstrated in the past but may be linked to water availability, because the lag phase was evident in two cultivars in this study during the driest year. A sigmoidal growth curve has also been demonstrated in blueberry (Young, 1952).

Temperature accounts for greater than $80 \%$ of the variability in the accumulation of fresh weight by a cranberry (DeMoranville et al., 1996). In particular, high July temperatures and low August temperatures increased the number of days needed to accumulate $0.5 \mathrm{~g}$ of fresh weight (DeMoranville et al., 1996). In this study, days in July in which maximum daily temperature exceeded $29^{\circ} \mathrm{C}$ were greatest in 2002 (10) followed by 2003 (six) and then 2004 (one). Fruit dry weight and diameter were very similar in 2003 and 2004 but were lower in 2002 (Fig. 5), confirming the negative influence of high temperature in July.

With respect to vegetative growth, upright number (data not shown), total leaf dry weight in 'Howes' and 'Stevens' (Fig. 3B$\mathrm{C})$, and leaf area in all cultivars before the accumulation of $\approx 3000$ GDD (Fig. 4) were lowest during the hottest year (2002). Leaf area per upright was greatest in the early portion of the season in 2004 (Fig. 4), which was also the coolest growing season. These data indicate that high temperature may also have a negative impact on vegetative growth of cranberry. Studies to determine the effect of temperature on net carbon exchange rate in cranberry have been inconclusive (Vanden Heuvel and Davenport, 2005; T.R. Roper, unpublished data); however, higher temperatures have been thought to reduce net carbon exchange in cranberries grown in the greenhouse (Vanden Heuvel and Davenport, 2005).

Although competition between fruits on an upright has been investigated (Baumann and Eaton, 1986; Birrenkott and Stang, 1990), competition between fruit and upright growth has not been studied in cranberry. In red raspberry, vegetative canes (i.e., primocanes) are a very strong sink through to the peak of fruiting (Fernandez and Pritts, 1994) and therefore compete with the fruit for carbon resources. The negative correlation reported by Bergman (1954) between upright density and yield, and between upright length and yield for 'Early Black' and 'Howes', indicates that sink demand from vegetative tissues may reduce yield in cranberry. These data are supported more recently by a negative correlation between new growth and yield noted on 'Stevens' in Wisconsin (Kosola et al., 2006). DeMoranville (1992) determined the relationship between date and new shoot dry weight to be asymptotic in 3 of 4 years but linear in 1 year of the study, suggesting that developing new shoots compete with developing fruit, particularly through the summer.

Data from this study indicate a general shifting of resource allocation from leaf area and dry weight accumulation to fruit growth at $\approx 1500$ GDD (Figs. 3 and 4 ), when the initial surge of fruit growth begins (Fig. 5). After the initial surge in fruit growth, leaf area and dry weight accumulation resumes at roughly 2300 GDD (Figs. 3 and 4), resulting in a competition for resources with the developing fruit until after 3000 GDD. The lag phase in fruit diameter and dry weight accumulation that is sometimes noted may be partially the result of the resumption of leaf growth. Root growth was not studied in this experiment and has tended to be variable between years in other studies (DeMoranville, 1992). However, an increase in root growth has been shown to occur in early July ( 2 of 3 years) with another peak occurring through late July to mid-August in all years studied (DeMoranville, 1992). Because a rapid period of fruit growth tends to occur in late July through early August (Fig. 5), root tissue, 
shoot tissue, and fruit may all compete for resources during the hottest portion of the growing season, when carbohydrate concentration of uprights and roots is extremely low (Botelho and Vanden Heuvel, 2006). Management tools to maximize carbohydrate availability during that period (such as evaporative cooling) should be investigated to optimize vegetative and reproductive growth.

\section{Literature Cited}

Baumann, T.E. and G.W. Eaton. 1986. Competition among berries on the cranberry upright. J. Amer. Soc. Hort. Sci. 111:869-872.

Bergman, H.F. 1954. Flowering and fruiting characteristics of the cranberry in New Jersey. In: Proc. 84th Ann. Mtg. Amer. Cranberry Growers' Assoc. p. 17-27.

Birrenkott, B.A. and E.J. Stang. 1990. Selective flower removal increases cranberry fruit set. HortScience 25:1226-1228.

Botelho, M.R. and J.E. Vanden Heuvel. 2006. Preliminary assessment of the impact of current flooding practices on non-structural carbohydrate concentrations of cranberry. HortTechnology 16:277-285.
Chandler, F.B. 1952. Preliminary report on the development of cranberry fruit. Cranberries 17:6-7.

Dana, M.N. 1983. Cranberry cultivar list. Fruit Var. J. 37:88-95.

Davenport, J.R. 1996. The effect of nitrogen fertilizer rates and timing on cranberry yield and fruit quality. J. Amer. Soc. Hort. Sci. 12: 1089-1094.

Davenport, J.R. and N. Vorsa. 1999. Cultivar fruiting and vegetative response to nitrogen fertilizer in cranberry. J. Amer. Soc. Hort. Sci. 124:90-93.

DeMoranville, C.J. 1992. Cranberry nutrients, phenology, and $\mathrm{N}-\mathrm{P}-\mathrm{K}$ fertilization. PhD diss. Univ. of Mass., Amherst, MA.

DeMoranville, C.J. 2004. The 'Early Black' cranberry. J. Amer. Pom. Soc. 58:126-128.

DeMoranville, C.J., J.R. Davenport, K. Patten, T.R Roper, B.C. Strik, N. Vorsa, and A.P. Poole. 1996. Fruit mass development in three cranberry cultivars and five production regions. J. Amer. Soc. Hort. Sci. 121:680-685.

Fernandez, G.E. and M.P. Pritts. 1994. Growth, carbon acquisition, and source-sink relationships in 'Titan' red raspberry. J. Amer. Soc. Hort. Sci. 119:1163-1168.

Hawker, G.M. and E.J. Stang. 1985. Characterizing vegetative growth and fruit development in cranberry (Vaccinium macrocarpon Ait.) by thermal summation. Acta Hort. 165:311-324.

Kosola, K., D. Randhawa, S. Stackpoole, and B.A. Workmaster. 2006. Nitrate in cranberry irrigation water-Initial observations during the 2005 growing season. Proc. of the 2006 Wisconsin Cranberry School. 30 May 2008. <http:// www.hort.wisc.edu/cran/pubs_archive/proceedings/ pubs_proceedings_2006.html>.

Roper, T.R. 1999. Cranberry cultivar acreage survey. Cranberries 63:13-14.

Roper, T.R. 2001. 'Stevens' cranberry. J. Amer. Pom. Soc. 55:66-67.

Roper, T.R., K.D. Patten, C.J. DeMoranville, J.R. Davenport, B.C. Strik, and A.P. Poole. 1993. Fruiting of cranberry uprights reduces fruiting the following year. HortScience 28:228.

Vanden Heuvel, J.E. and J.R. Davenport. 2005. Effects of light, temperature, defoliation and fruiting on carbon assimilation and partitioning in potted cranberry. HortScience 40:1699-1704.

Vanden Heuvel, J.E. and J.R. Davenport. 2006. Growth and carbon partitioning in cranberry uprights as influenced by nitrogen supply. HortScience 41:1552-1558.

Young, R.S. 1952. Growth and development of the blueberry fruit (Vaccinium corymbosum $\mathrm{L}$. and $V$. angustifolium Ait.). Proc. Amer. Soc. Hort. Sci. 59:167-172. 